\title{
Analisis faktor yang mempengaruhi keputusan pemilihan program studi spesialis radiologi kedokteran gigi
}

\author{
Chrisna Ardhya Medika1*, Rellyca Sola Gracea² (iD, Lusi Epsilawati (iD, \\ Azhari' ${ }^{1}$ Farina Pramanik
}

\begin{abstract}
Objectives: This paper aims to determine the factors that influence the decision making of a general dentist to become a dentomaxillofacial radiologist, particularly in Indonesia.

Material and Methods: This research used a descriptive design with survey techniques, and the research samples were residents of dentomaxillofacial radiology residency program and dentomaxillofacial radiologists in Indonesia. This research was conducted by the way respondents filled out questionnaires, based on the concept of

marketing and purchasing on the expertise of dental radiology specialists.

Results: There are variations in answers that are dominated by the value of product purchases as a dental radiology specialist is urgently needed.

Conclusion: Dentomaxillofacial radiologist is a profession that is rarely found in Indonesia so it becomes a reliable job in the future as more experts are needed. The promotional activities of its residency program are still much of lack.

${ }^{1}$ Departemen Radiologi Kedokteran Gigi, Fakultas Kedokteran Gigi, Universitas Padjadjaran, Bandung, Indonesia, 40132

${ }^{2}$ Departemen Radiologi Kedokteran Gigi, Fakultas Kedokteran Gigi, Universitas Gadjah Mada, Yogyakarta, Indonesia, 55281

*Correspondence to:

Chrisna Ardhya Medika

凶dentchriest@gmail.com

Received on: May 2020

Revised on: June 2020

Accepted on: August 2020

Keywords: factor analysis, dentomaxillofacial radiology, dentomaxillofacial radiologist

Cite this article: Medika CA, Gracea RS, Epsilawati L, Azhari, Pramanik F. Analisis faktor yang mempengaruhi keputusan pemilihan program studi spesialis radiologi kedokteran gigi. Jurnal Radiologi Dentomaksilofasial Indonesia 2020;4(2)114. https://doi.org/10.32793/jrdi.v4i2.560

\section{PENDAHULUAN}

Kebutuhan akan sekolah lanjut seperti program spesialis sudah menjadi salah satu kebutuhan masyarakat kita. Melanjutkan pendidikan lanjutan di lembaga perguruan tinggi juga merupakan salah satu tujuan dalam masyarakat untuk meningkatkan pendidikan yang fokus pada satu bidang konsentrasi yang dibutuhkan untuk masyarakat. ${ }^{1}$ Meningkatnya keinginan masyarakat untuk memiliki karier terutama dibidang spesialisasi di bidang kedokteran gigi, mendorong upaya lanjutan studi. Persaingan yang ketat dalam dunia kerja khususnya dibidang spesialis kedokteran gigi, membutuhkan strategi bisnis tertentu untuk dapat bertahan dalam mewujudkan layanan yang terbaik bagi stakeholder. Tersedianya sumber daya manusia yang menguasai keilmuan terutama di bidang spesialisasi tergantung dari banyaknya jumlah pemilihan jenis program studi yang diminati. $^{1,2}$

Perguruan Tinggi adalah organisasi yang bergerak dalam usaha pendidikan, dimana dijual jasa pendidikan yang harus dipasarkan kepada konsumen. Dengan demikian, lembaga pendidikan dapat dianalogikan sebagai lembaga pemberi jasa kepada para konsumen (mahasiswa). Oleh karena itu, mereka adalah pihak yang berhak memberikan penilaian menarik tidaknya suatu lembaga pendidikan termasuk didalamnya program studi. Melanjutkan studi ke program lanjutan sepert program spesialis seperti investasi jangka panjang, sebelum keputusan diambil banyak hal yang terlibat, seperti pemakai (user) penggagas (initiator), pihak yang memengaruhi (influencer), pengambil putusan (decider), dan tentu saja faktor kepercayaan (trust). ${ }^{3,4}$ Banyak faktor yang harus dipertimbangkan sebelum seorang calon mahasiswa menjatuhkan pilihannya kepada salah satu program studi yang diminati. Proses pengambilan keputusan mungkin akan dimulai dengan penetapan tujuan lalu mengembangkan alternatif dan akhirnya menentukan pilihan terbaik. Sebagian orang mungkin akan melakukan pilihan secara spontan tanpa perencanaan, baik karena tergiur oleh promosi, pelayanan, fasilitas gedung dan lain-lain tanpa melakukan skala prioritas mana yang lebih dulu dilakukan. Tentu dalam menentukan pilihan memerlukan proses rasional yang sedapat mungkin objektif, karena akan berakibat jangka panjang dan terkait dengan pengorbanan yang besar, mulai dari waktu, persiapan, dana, dan sikap mental dari peserta didik. $^{4}$

Program Studi Spesialis Radiologi Kedokteran Gigi merupakan salah satu cabang keilmuan kedokteran gigi, yang menitikberatkan kemampuan dalam tindakan interpretasi gambaran image serta tehnik radiografi dalam rangka membantu pelayanan kesehatan kedokteran gigi. Program ini 
baru satu-satunya di Indonesia selama 10 tahun terakhir, dan lulusannya pun masih sedikit. Program Studi Pendidikan Spesialis Radiologi Kedokteran Gigi berdiri tepatnya pada tahun 2008 dan menerima peserta didik pertama kali pada tahun 2009, di Bandung pada Universitas Padjadjaran Bandung. Setiap tahun mahasiswa baru dari program studi ini selalu ada, walaupun jumlahnya tidak banyak akan tetapi program studi ini selalu berusaha untuk menawarkan hal yang terbaik bagi peserta didiknya. Program Studi Spesialis Radiologi Kedokteran Gig merupakan program studi yang tidak terlalu difavoritkan pada saat ini, untuk itu kepeminatan peserta didik perlu untuk diketahui demi majunya program studi ini. ${ }^{5,6}$

Berdasarkan fenomena ini, penulis berminat untuk melakukan penelitian pada semua peserta didik dan lulusan Program Studi Spesialis Radiologi Kedokteran Gigi berkaitan dengan faktor-faktor yang mempengaruhi keputusan dalam memilih program studi lanjutan khususnya Program Stud Spesialis Radiologi Kedokteran Gigi.

\section{BAHAN DAN METODE}

Penelitian ini berjenis survei analitik dimana populasi dan sampel yang dipilih adalah semua peserta didik dan lulusan Program Studi Spesialis Radiologi Kedokteran Gigi. Sampel yang mengikuti survei ini berjumlah 39 orang. Adapun variabel yang dipilih dalam melakukan survei terdiri dari 4 aspek yang terdapat dalam konsep pemasaran dari Kotler dan Armstrong yang terdiri dari sebagai berikut: ${ }^{3,4}$

\section{Konsep Produksi}

Konsep produksi adalah konsep pertama di dunia bisnis. Dimana konsumen akan memilih produk yang tersedia dan dinilai tidak mahal. Manajer produksi berorientasi pada pencapaian efisiensi produk, biaya rendah dan distribusi.

\section{Konsep Produk}

Konsep produk merupakan keadaan saat konsumen akan meminta produk yang paling berkualitas, memiliki performa atau fitur yang inovatif. Manajer yang fokus pada konsep ini membuat produk yang superior dan terus ditingkatkan dari waktu ke waktu. Produk yang baru atau produk yang baru ditingkatkan belum tentu sukses tanpa penetapan biaya, distribusi, pengiklanan dan penjualan yang tepat.

\section{Konsep Penjualan}

Konsep penjualan menetapkan penjualan yang agresif dengan upaya promosi, dimana jika tidak diterapkan maka produk tidak akan terjual secara memuaskan.

\section{Konsep Pemasaran}

Falsafah pemasaran yang berkeyakinan bahwa pencapaian sasaran organisasi tergantung pada penentuan kebutuhan dan keinginan pasar sasaran dan penyampaian kepuasan lebih efektif dan efisien dari pada pesaing.

Tabel 1. Distribusi jawaban dari keempat konsep dan tiap pertanyaan

\begin{tabular}{|c|c|c|c|}
\hline Produksi & Setuju & Ragu-ragu & Tidak Setuju \\
\hline 1 & 18 & 5 & 16 \\
\hline 2 & 19 & 6 & 14 \\
\hline 3 & 21 & 4 & 14 \\
\hline 4 & 19 & 9 & 11 \\
\hline 5 & 17 & 11 & 11 \\
\hline Produk & Setuju & Ragu-ragu & Tidak Setuju \\
\hline 1 & 29 & 10 & 0 \\
\hline 2 & 30 & 8 & 1 \\
\hline 3 & 21 & 3 & 15 \\
\hline 4 & 20 & 3 & 16 \\
\hline 5 & 16 & 11 & 12 \\
\hline 6 & 35 & 3 & 1 \\
\hline 7 & 31 & 4 & 4 \\
\hline 8 & 36 & 1 & 2 \\
\hline 9 & 39 & 0 & 0 \\
\hline 10 & 23 & 4 & 12 \\
\hline 11 & 37 & 1 & 1 \\
\hline Penjualan & Setuju & Ragu-ragu & Tidak Setuju \\
\hline 1 & 8 & 6 & 25 \\
\hline 2 & 10 & 11 & 18 \\
\hline 3 & 8 & 11 & 20 \\
\hline 4 & 30 & 5 & 4 \\
\hline 5 & 24 & 7 & 8 \\
\hline 6 & 20 & 16 & 3 \\
\hline Pemasaran & Setuju & Ragu-ragu & Tidak Setuju \\
\hline 1 & 24 & 11 & 4 \\
\hline 2 & 39 & 0 & 0 \\
\hline 3 & 37 & 1 & 1 \\
\hline 4 & 9 & 15 & 15 \\
\hline 5 & 26 & 5 & 8 \\
\hline
\end{tabular}


Tabel 2. Presentase dari distribusi jawaban sesuai skala

\begin{tabular}{ccccc}
\hline & \multicolumn{4}{c}{ Konsep (\%) } \\
\cline { 2 - 5 } & Produksi & Produk & Penjualan & Pemasaran \\
\hline Setuju & 47 & 74,3 & 42,3 & 69,2 \\
\hline Ragu ragu & 8,9 & 5,1 & 11,5 & 8,9 \\
\hline Tidak Setuju & 44,1 & 20,6 & 46,2 & 21,9 \\
\hline
\end{tabular}

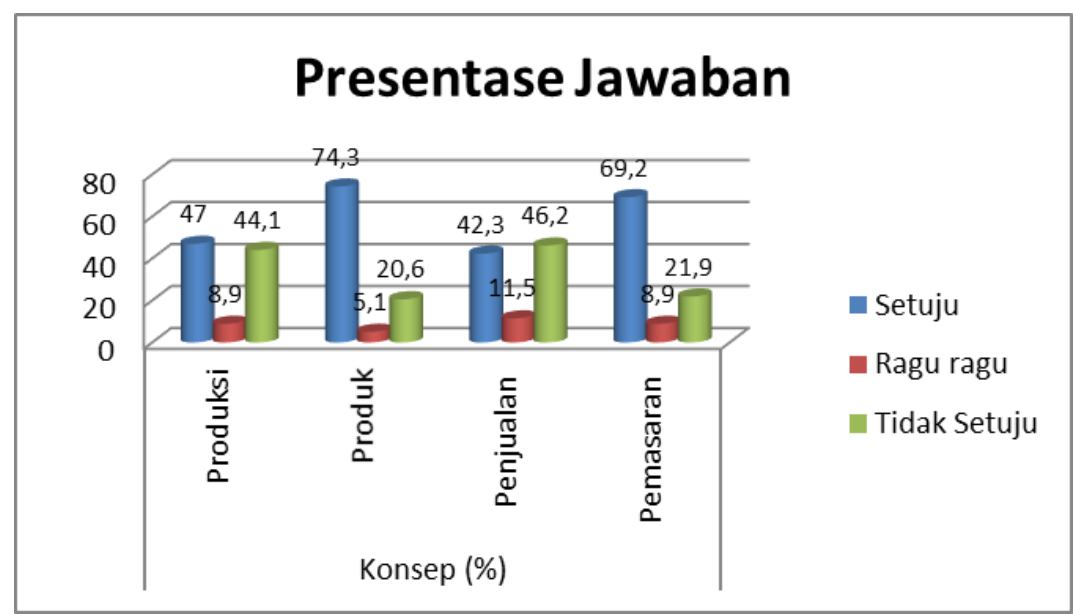

Gambar 1. Grafik distribusi persentase dari jawaban

Penelitian ini akan menilai pengaruh keempat faktor di atas pada proses pemilihan program studi. Masing-masing faktor disajikan menjadi 5-11 kuisioner. Skala yang digunakan adalah skala Guttman dengan skala jawaban setuju, ragu-ragu dan tidak setuju. Skor yang diberikan adalah 2 untuk setuju, 1 untuk ragu-ragu dan tidak setuju 0 .

\section{HASIL}

Hasil penelitian ditunjukkan pada Tabel 1 dan 2 serta Gambar 1. Berdasarkan analisis sampel sebanyak 39 orang didapatkan hasil penelitian menunjukkan jawaban dari sampel penelitian yang cukup bervariasi. Pada konsep produksi dan konsep penjualan, terdapat angka jumlah atau persentase yang tidak jauh berbeda antara jawaban setuju dengan tidak setuju. Hal ini berbeda dengan konsep produk dan pemasaran yang memiliki jawaban setuju jauh lebih dominan sehingga keduanya menempati urutan tertinggi.

\section{DISKUSI}

Dalam memilih program studi seorang mahasiswa dianalogikan sebagaimana konsumen yang akan memilih produk tertentu. Pemilihan seperti ini akan selalu didasari oleh seperangkat alasan logis dan psikologis. Persepsi masing-masing mahasiswa pun akan sangat bervariasi. Responden yang terkumpul adalah 39 orang yang berasal dar mahasiswa aktif dan lulusan. Berdasarkan hasil penelitian faktor produk dan pemasaran menempati urutan tetinggi. ${ }^{1,7}$ Kata produk yang dimaksud dalam penelitian ini merupakan indikator untuk segala hal yang berhubungan dengan pertanyaan yang diajukan seputar silabus, kesesuian materi serta pertanyaan yang bekisar kegiatan penyelenggaraan perkuliahan Berdasarkan hasil penelitian terdapat $74 \%$ setuju bahwa kegiatan pembelajaran di Program Studi Radiologi Kedokteran Gigi cukup menarik, inovatif dan menantang sehingga para peserta didik merasakan manfaat dan perubahan ilmu sesuai dengan yang diharapkan. ${ }^{1,2,7,8}$

Hal selanjutnya yang menjadi nilai baik adalah pemasaran. Arti dari kata pemasaran dalam hal in adalah kemampuan bersaing dan kebutuhan pasar akan seorang yang ahli di bidang radiolog kedokteran gigi. Banyak responden yang menyatakan bahwa pendidikan pada progran studi ini akan menciptakan peluang kerja lebih besar dimana permohonan pasar sangat banyak, mengingat keahlian di bidang ini masih sangat minimal. ${ }^{3,4,9,10}$

Berdasarkan hasil penelitian bahwa yang memperoleh nilai paling kecil adalah dari segi penjualan. Penjualan adalah kemampuan dari program studi untuk mempromosikan program studinya. Responden merasa bahwa informasi mengenai keberadaan program studi ini sulit diperoleh, kebanyakan dari mereka memperoleh informasi dari tempat asal mereka bekerja. Leaflet dan media informasi hampir tidak bermanfaat untuk mempromosikan program studi ini. ${ }^{5,6,11,12}$ 


\section{SIMPULAN}

Kesimpulan yang dapat diambil dari hasil penelitian bahwa Program Studi Spesialis Radiologi Kedokteran Gigi merupakan program studi yang dipercaya oleh pasar dengan menjanjikan peluang kerja yang baik karena kurangnya tenaga ahli dipasaran, dan program studi ini mampu memberikan penyelegaraan pendidikan yang baik bagi peserta didiknya. Hal yang dirasa sangat kurang adalah dari segi promosi.

\section{DAFTAR PUSTAKA}

1. Kotler, Philip and Amstrong,Gary, Principles Of Marketing, Fourteen Edition, Pearson Education Limited, England. 2012,

2. Kusumawati Andriani,Privatization and marketization of Indonesian public universities : a systematic review of student choice criteria literature Research Online Sydney Business School - Papers. 2010

3. Kotler,Philip dan Amstrong,Gary, Dasar-dasa Pemasaran,Penerbit PT Indeks Kelompok Gramedia, Jakarta.2009

4. Kotler, Philip dan Keller,Kevin, Manajemen Pemasaran, Penerbit Prenhalindo, Jakarta.2009

5. Simarmata Jonner. Korelasi Motivasi Kerja dengan Kinerja. Jurnal Akademika. 2002.6 (1).

6. Wagner K,Fard, P. Y. Factors Influencing Malaysian Students Intention to Study at a Higher Educational Institution. Chinese American Scholars Association New York, New York, USA Retrieved 11 July, 2009, from http://www.gcasa.com/PDF/ malaysia/Wagner- Fard.pdf

7. Armstrong. Manajemen Sumber Daya Manusia. Jakarta: Alex Kompotindo.2009

8. Gómez-Mejía.Managing Human Resources. USA: Pearson Education.2012

9. Martoyo.Manajemen Sumber Daya Manusia. Yogyakarta: BPFE. 2007

10. Marwansyah. Manajemen Sumber Daya Manusia. Bandung Alfabeta.2010

11. Mathis,Jackson, John. Manajemen Sumber Daya Manusia. Jakarta: Penerbit Salemba Empat.2010

12. Siagian, Sondang. Sistem Informasi untuk Pengambilan Keputusan. Jakarta: CV Haji Masagung.2004 